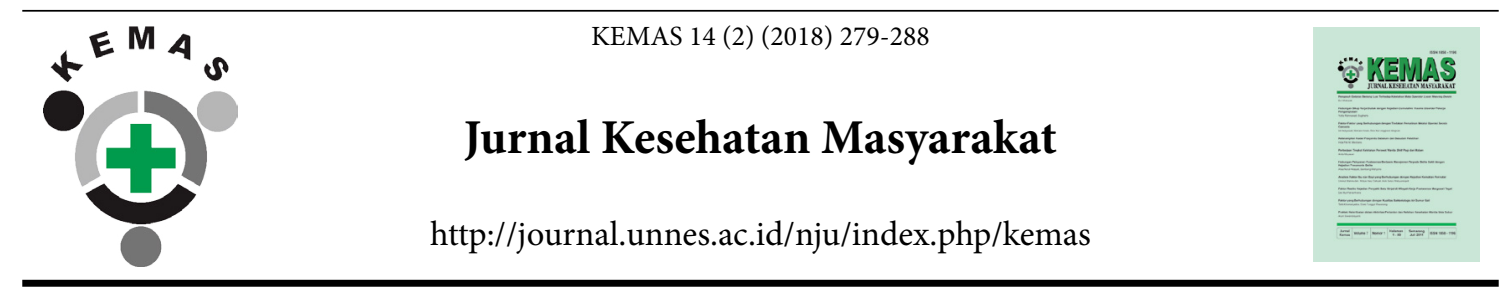

\title{
The Community Satisfaction and Participation of the Health Planning Process in Primary Health Care
}

\author{
Ayun Sriatmi ${ }^{1 凶}$, Sutopo Patriajati $^{1}$, Eka Yunila Fatmasari ${ }^{1}$ \\ ${ }^{1}$ Public Health Faculty, Diponegoro University, Semarang, Indonesia
}

\begin{tabular}{l} 
Article Info \\
\hline Article History: \\
Submitted October 2017 \\
Accepted May 2018 \\
Published November 2018 \\
\hline Keywords: \\
Service satisfaction, \\
community participa- \\
tion, PHC planning \\
\hline DOI \\
https://doi.org/10.15294/ \\
kemas.v14i2.11717
\end{tabular}

\begin{abstract}
PHC as a public service institution is obliged to comply with the public service standard regarding with the community participatory principle. This research aimed to describe the community satisfaction and participation level in the PHC planning. Descriptive qualitative with 14 informants from 4 PHC in districts of Semarang and Kudus. Data were collected by indepth interview and analyzed with content analysis. Communities are satisfied with the PHC service because of the good service and uncomplicated procedure, which has impact to increase the daily visits. This situation makes queue time longer and the fatigue level of the officer tends to decrease the satisfaction. Communities have been involved in the planning mechanism, although only limited to the situational analysis phase. The Health Office is expected to facilitate the addition of PHC personnel and PHC also have to fulfill the need of human resources through the plans that have been done.
\end{abstract}

\section{Introduction}

Health is a field where the planning authority is given to the regions as a form of government decentralization. Decentralization not only focuses on delegating authority from the central to local government (Pudjirahardjo \& Sopacua, 2006), but sistematically directs the public involvement in determining the objective, planning, financing and monitoring mechanism, including health. With the goodgovernance paradigm, the new governance orientation emphasizes on the accountability, transparency and participation principles (Dwiyanto, 2003) because of the assumption that the government performance as a public service provider is less effective. Therefore, there must be equality, balance and participation between the government, private and community (Pudjirahardjo \& Sopacua, 2006; Dwiyanto, 2003). Good governance as an approach togovernment morality towards a humanely service prioritizes the community involvement and participation (Dwiyanto, 2003).

Law No.25 of 2009 on Public Service mandatess that the standards of public service are the benchmarks and guidelines in the implementation and assessment of service quality to the public. All of the public services must pay attention on how public rights are implemented appopriately and correctly (Dwiyanto, 2003). In the health sector, the monitoring of community satisfaction on health services is an important component in 
measuring and improving the organizational effectiveness and must be a part of quality development plans, as is the case in Sri Langka, Malaysia and other low and middle income countries. (Hazilah Abd Manaf, 2012; RannanEliya et al., 2015; Kok et al., 2015)

Primary Health Care (PHC) as the technical unit (UPT) of Regency Health Office is a public service institution which is responsible and provide a first-rate health "service" for the community. PHC are obliged to obey the public service principles. Currently, PHC focuses more on how to meet the targets regardless of how the "process" is implemented, whereas the performance measurement is also including the expectation process (how the work done) and the expectation of the outcomes (Choudhary \& Puranik, 2014). On the other hand, the quality of PHC service has not fully satisfied the community, as research at PHC of Ngaliyan Semarang (Listyoningrum et al., 2015). The study at Duren Health Center showed that data quality at PHC only reached 66\% (Dharmawan et al., 2015). More than $50 \%$ of the people are not satisfied with the quality of Poncol Health Center service from 5 dimensions of satisfaction (Hasbi, 2012). There is a discrepancy between hope and reality that affects public dissatisfaction to $\mathrm{PHC}$ of Kalirungkut Surabaya, especially at the speed of service, the discipline of service workers, and the timeliness of service (Chasanah \& Amanah, 2013).

In the implementation of the management function, most $\mathrm{PHC}$ also have not conducted survey on the consumer satisfaction and needs which became the initial step on the PHC planning and also as the indicator of public service performance standard. but it is only conducted when there is a PHC acreditation. For the PHC that do not or have not accredited, they tend not to conduct that survey (Prihandari, 2014). Accreditation (including ISO 9000) as a tool for measuring standards for work structures that are expected to bring positive implications on community satisfaction. On the other hand, PHC is the health facility with the most service on treating JKN participants (79.5\%). It is recognized that PHC have complex duties and responsibilities in JKN era even though the PHC resources (human resources) are limited.

As the core of PHC management, planning aims to solve the regional health problem. All of the managerial activities are adjusted and directed by the planning, which often seems complicated with some intersect data. The PHC activities and program planning tend to be a routine and only based on the activity in previous years. The heads of PHC must be aware of the PHC problems which develops in the working area and capable to be motivators and mobilisers of community groups. Therefore, in PHC Performance Evaluation Manual be explained that every PHC is equipped with the managerial instruments such as: PHC Level Planning (PTP), PHC Mini Workshop; PHC Performance Assessment (PKP); and the resource management, including tools, medicines, finance and personnel, and supported by the record and report system management (SIMPUS) and the efforts to increase the service quality.

According to Mebri (2009), there is no PHC which the planning mechanism refer directly to the PHC Level Planning (PTP) guideline in Jayapura City (Mebri, 2009). PHC only performs the 4th step of the four requirements from PTP guideline which is the formulation of Activity Implementation Planning (RPK), meanwhile the preparatory step, analysis step and the preparation of Proposed Activity Plan (RUK) step are not performed. A special training on the PHC level planning have never been organized, besides the financial limitation factor, also because the planning has become a routine for PHC (Dhewi et al., 2013).

Although the PHC planning is pursued according to the stages in PTP (PHC Level Planning) guidelines, the "process" of situational analysis as the initial step of the planning has not yet accomodated the needs and at the same time involves the community participation in providing inputs through the use of needs and satisfaction surveys, including the role of stake holders and other cross sectors. The community needs survey forms the basis assessment of health service input and process, especially in determining the priority scale of the program. The satisfaction survey is an outcome assessment and also the initial 
indicator of PHC performance assessment. Based on the condition, this research is also aimed to describe the community satisfaction and participation to the health service and planning quality in PHC.

\section{Method}

It is a descriptive qualitative research, aimed to describe indepth (exploration) the various facts about community satisfaction to the health service and the participation in the planning mechanism. The research subject were 14 people, consisted of main informants (10 people) as user of health services and 4 people as an triangulation informant who have responsibility for PHC planning process. The research is located in 4 PHC, which 2 PHC in Kudus Regency (Rejosari and Jepang) and 2 PHC in Semarang City (Rowosari and Pudakpayung).

Measurement of community satisfaction variable is based on indicator of KepMenPAN No: KEP-25/M.PAN/2/2004 dated February 24, 2004 on Guidelines for Preparing Consumer Satisfaction Index of Service Unit Government Institution consisting of 14 indicators, but in this study it is summarized into 4 indicators: service procedures; the ability of officers; justice of service; as well as the convenience of the service environment area. The measurement of community participation variables in the planning process emphasizes the shape and intensity of participation and participatory barriers. The primary data collection were conducted using indepth interview and the secondary data through literature study, review of various documents and reports related to $\mathrm{PHC}$ planning process. The data analysis using content analysis.

\section{Result and Disccusion}

Most of the informant of the community are men with the age range 38-62 years old, married, educated at leaston highschool(equal), although there are some undergraduate (S1). Generally are community leaders and regional government apparatus (Village Head, RW, PKK, etc.). They also become consumers of health services held by the PHC. The triangulation informant as person who responsible for PHC planning process is generally female, with age range 31-56 years old and education Diploma (D3) and undergraduate (S1). Average working period of 9 years (range 6 months - 25 years).

In the service procedure, most of the people stated that the service procedure in PHC is now better than before, easier and not complicated. The people who visit do not need to swirl around in confusion to get the service. The registration counter of $\mathrm{PHC}$ is also located directly in the front area of the waiting room entrance, as well as for the location of other service units which can be accessed easily. In this health insurance (JKN/BPJS) era, people are only required to show their health insurance (BPJS) card or Identity Card (KTP) when they register in the registration counter before they are called to be served. Information about the service is also clearly provided by the $\mathrm{PHC}$ staffs. Meanwhile the written information in the flow chart containing various announcements and informatios about $\mathrm{PHC}$ and the service are placed in the form of banner, street banner or in the PHC walls, such as service flow, referral flow, registration flow and so on. Every time come to visit, people is always asked by identity through the BPJS card/KIS and or KTP or other certificate owned for matching data visitors (patients).

"Good, a good service..it's much better now..good.., generally the community here satisfying with PHC services. Also easy do not need to whirl around.." (IU 4)

"As long as we bring card or ID card it is done, free, only need to wait to be called" (IU 5)

"Yes, if we do not know they will explain..., so we can prepare the requirements that need to be brought then how the step is.. good and easy actually.." (IU 7)

The requirements to get a service is considered very easy by the community, because only by showing the card (BPJS/KIS/Jamkesda) and or ID card, people can get a PHC service. The service is also free of charge. However, some PHC triangulation informants admit that many people tend to "take it for granted" by not bringing their cards and they do not want to know, so it becomes an obstacle and difficulty in getting the service because they are asked to go home (if possible) to bring the requirements 
needed. Not all people are cooperative so the staffs feel annoyed and less pleased. This condition is recognized by the community informants as a result of their ignorance and uncertainty about the service procedure. Also explained by PHC officials that the condition is due to mis communication. However, basically people feel happy with the presence of PHC in their area which is very helpful in providing health facility they need.

\footnotetext{
"As long as you bring the card or ID card it is done, free, only need to wait to be called"(IU2)

"Sometimes there are people who just do whatever they want. who like to just and desperate so annoying." (IT 3)
}

In the aspects related of the ability of health officers in providing services, most people say is good, smart and able to overcome the problem. They are also considered to have good knowledge and skills. The ability of health officers to carry out their duties becomes an important component to know the quality / service quality that will have implications on the level of community satisfaction. The ability of health officers can be interpreted as the level of expertise, skills and experience possessed by them in providing needed services and or solving existing health problems. Most of the people said that the health officers were able to work well for various reasons, including: already appropriate education, according to job duties; according to the experience owned and also according to the needs of the community itself. They are also considered to have good knowledge and skills, according to their education and expertise.

Health officers or staffs who provide the service also clear whom the person and their field of duty. Regarding with the clarity of the staffs who provide the service, most of the people stated that the staffs (health officers) are good and do their respective duties, so it can be assumed that the satisfaction about the clarity of staffs is good. In their opinion, the staffs already do their job according to the procedure. The staffs are also discipline in time because the opening hour of PHC is clear. Usually the staffs do not come late in providing the service. Even if there is staff who is absent due to permission or another duty, there is always a replacement. It is also considered as the responsibility of PHC in serving. People are also satisfied by the readiness of PHC staffs so far, because when the people/patients need service, staffs who provide service are in place. This, of course, is very pleasant.

"...study as a doctor to be a doctor..., study as a midwife to be a midwife.." (IU 2)

“...have many experiences, of course they are capable.., moreover the education is appropriate so why do not trust?.." (IU 8)

Although usually people assess the working ability of PHC staffs so far is good enough, but there are some issues which are considered unsatisfying by the public that is in the aspect of service speed. Some people still consider that the service in PHC sometimes too long and time consuming. This condition is also recognized by the PHC staffs. The reason for the long and delay is caused by the large number and the queue of patients everyday, while the number of staffs are lacking. The average of $\mathrm{PHC}$ receive more than 100 patients each day (even more than 200 patients per day for certain days such as the hajj season) is considered to be heavy and time consuming for the health officers, especially when they are faced with another program duties outside (tasks that outside the PHC building), such as visiting pregnant and postpartum mothers, visiting baby with LBW (low birth weight), Posyandu, School Health Unit (UKS), immunization and so on. This result is similar to the research of Chasanah \& Amanah which shows the dissatisfaction in the speed of service, discipline and punctuality of service at PHC of Kalirungkut Surabaya (Chasanah \& Amanah, 2013). Elements of performance that related to the speed of service and convenience of service is still felt less good and impact on dissatisfaction in PHC of Kedungmundu Semarang (Tunjungsari et al., 2014).

On the other hand, people also know and recognize that the patient visits are increasing 
everyday. They acknowledge that after the free health program is proclaimed by the government (both at PHC or in Hospitals), people come to check their health. According to them, people come to PHC because they need the service and during this time or before this they did not get checked because they were afraid and constrained by the coat they need to prepare in advance which they did not have so in the end they chose not to go to PHC. With the existence of free health service, they who previously afraid to go to PHC become more courageous. People recognize that the free health care program is beneficial for them because they do not need to spend any cost (out of pocket) when their family are sick and needs treatment. They also hope this program can be continued forever.

The increasing number of visits and limited personnel causes the problem of too long in providing services because the queue is getting longer. However, people hope that there is PHC awareness to provide a sufficient waiting chairs and space because currently people have to stand for quite long. There is an effect gap from the number of visits to the primary care that impact on patient satisfaction of services in Europe (Sanchez-Piedra et al., 2014). The issue of availability and readiness of PHC ambulance is also considered to be unsatisfying. One of the informants complaints about the dificulty in borrowing PHC ambulance to deliver a patient because of several reasons such as no permanent driver, damaged, out of working hour, etc. Although there are complaints submitted, but people in general are satisfied with the staffs performance in the service speed aspect.

\footnotetext{
"Usually it is good and satisfied enough with the PHC service" (IU 10) "Ummm it is hard if we start queueing, long and tiring...we also feel sorry when the patient need to stand for long.., the waiting chairs must be added to be sufficient.." (IU 5)

"It is hard to borrow ambulance... difficult, the reason sometimes no driver, over the work hour or the car is broken.." (IU 7)
}

Related to the justice aspect of service, the community stated that PHC never discriminate the patients who come. All people who come are served well and fair. People perceive the service fairness as a service that does not discriminate the people (poor and rich), far-near and workers or enterpreneurs (termed as employers or bosses). The fairness principle is conducted through the service regardless of socioeconomic status, disease status and other status. People recognize that for certain cases, they are also often asked to defer when there is new patient coming who are "perforce" to take precedence because of the critical condition. However, people still not perceive it as injustice, even they consider it as a form of service fairness as well, because a critical patient must get a different attention than the patient with non critical condition (not serious). People are also considered that PHC staffs never discriminate the patient who come. The staffs are also considered to be fair in doing their duties.

One of the forms of fairness in PHC service is the right in getting free health care for all people. In practice, this understanding according to staff's perspective makes the public demand that all services should be free and free of charge, inspite of the unclear and even the absence of rule and regulation. Moreover, many people who are actually have a minor disease and easily cured with enough rest and regular healthy food consumption come in to be checked in PHC. This will increase the number of patients and longer queue. People understanding of health promotional and prevention principle is still lacking. The free health service is considered to give a great benefit for the pregnant mother who also receive free pregnancy and giving birth services at PHC.

\footnotetext{
"Now it is nice that there is a free service so the people do not need to pay to be examined in PHC..free treatment, delivering...eh giving birth is also free.. We thank the government.." (IU 9)

"The staffs are good.., we are well treated.. nothing peculiar" (IU 10)

"The staffs said that for critical patient, the rule is they need to be treated first..it will be too bad if something happen.. It is also explained by the
} 
staffs..., people can accept that.." (IU 4)

"Actually just enough rest but still come. it's more and more queues." (IT 1)

Regarding with the fairness and certainty of service charges, all informants stated that there is no problem regarding with the cost because all of the services in PHC are free of charges. For all people who can show the ID card (KTP) or bring their health insurance card (BPJS/KIS or Jamkesda), they will automatically get the service. The referral service to the hospital is also free and facilitated by PHC.

\footnotetext{
"There is no problem...it is free...so no need to pay...”(IU 2)

"The service is free... just by showing KTP then all services received free..." (IU 6)

"Yes so... we sometimes also confused because they all want it all for free, but the rules and regulations do not yet exist and are not clear yet too... But if not served it will be a problem and we are ultimately blamed.." (IT 2)
}

Related to the comfort of PHC environment, several informants said they were satisfied to see and feel the surrounding of PHC is now a good building and arranged neatly. They are proud of the condition, facility, and convenience of PHC. PHC is also clean with a wide parking area, quiet and even some of the rooms are equipped with AC (air conditioning) adding their convenience. Besides the satisfying convenience, people also think that during this time the PHC staffs are very kind and friendly. The friendliness aspect is one of the satisfactory aspects which is important to be concerned. They are efficient and patient in giving direction and explanation when there is problem/constraint faced by the people. The way in delivering and explaining is considered well enough, clear, polite and appropriate with the ethics. According to the people, this thing must be maintained and increased for the people to feel happy and later will also feel owning the PHC or "handarbeni" (the feeling of owning). PHC is considered to give the best service so far to all levels of community.

"It is already good... they are well mannered, humble, no problem.." (IU 1)

"Environment?..it is good and satisfying. People seem to be comfortable, there is a waiting room, enough car park...PHC is clean, quiet... There is examination room with AC so it is more comfortable and cold..nice.." (IU 7)

"Indeed now all the PHC renovated let alone accreditation preparation .., in order to provide the best service for people..." (IT 3)

In relation to the $\mathrm{PHC}$ planning process, most of the key informants stated that they were not directly involved, although they were often invited by the PHC to attend certain events. They are not very familiar with the planning of PHC. In essence, the public or community only wants that the PHC activities in accordance with the needs of the community (can meet the expectations of the community). People also want to give a direct input when there are meetings and discussions such as "rakordes" (village coordination meetings), FKD (village health forum) and so on. Furthermore, it is stated and expected that the meeting time is adjusted to the availability of community time so that citizens (the community) can follow it or participate. The same statement was also conveyed by informant triangulation that the involvement and participation of the community is considered to be good enough to participate in the PHC.

"Often there is an invitation from the PHC, yes we came ... asked for input for the upcoming PHC program .. But I do not understand it is for planning or what..." (IU 9)

"Essentially we want the puskesmas can help meet the needs of the community, that's the hope" (IU 5) "We actually want to attend, so if it can be adjusted for this activity to be held at night so we can participate... Alhamdulillah, PHC respond well..."(IU 7) 
The community involvement in the planning mechanism according to $\mathrm{PHC}$ informant is adequate to the step of giving inputs, because people (community) usually have not understand and distinguish between needs and demands. People usually perceive demands (desire) as their needs, which ultimately trigger the conflict between community (as consumer) and PHC staffs or health officer as the service facilitator (provider), because it is recognized that not all the wishes can be fulfilled. To guarantee the cross sector involvement, a collaboration and coordination with $\mathrm{PHC}$ is needed.

\footnotetext{
"The most adjustable is if the people give input about what they expect and seems that if it is more than that it is impossible, right?" (IT-1)

"For us, subdistrict plays a big role in monitoring and evaluating every 3 months which is also derived in village level... We also have SK regarding with monitoring cross section mini workshop (lokmin)..” (IT-4)
}

One of the constraints when involving community in planning is the people's lack of understanding about the procedure in PHC and the community needs, which often resulted in turmoil and conflict. People demand something but in procedure it can not be done by PHC. This condition is often causing complaints and judgements that PHC is less caring to the needs of people. In addition, people's complaints are also tend to point at the curative programs and do not look at the preventive and promotive programs. Some solutions are done by PHC such as by giving socialization about what can be and can not be done by PHC and what can be done by the village about the health programs. In addition, PHC also give an understanding that the job of PHC besides in curative also conduct the promotive and preventive programs. One of the PHC stated that the absence of people in the $\mathrm{PHC}$ invitation is because there is no transport money provided. Meanwhile according to the government rule, transport expenditure is not permitted (no money) if the distance between the house and PHC is less than $5 \mathrm{~km}$. As a solution, PHC tend to do socialization through regular meetings in village/RW/RT out of the working hour so there is no transport cost needed.

\begin{abstract}
"It is hard when people sometmes do not understand about the procedure in PHC.., so it is considered less caring...besides, people also only want the curative program and not the promotive preventive efforts." (IT 1) "People usually do not want to come if there is no transportation money...so they are often do not come...whereas we can not giving out the money if the distance is less than $5 \mathrm{~km}$..the rule is like that.." (IT-2)
\end{abstract}

Although on the one hand there is a constraint in collecting people by $\mathrm{PHC}$ because there is no transport money, this condition do not happen to all health cadres in PHC. According to the information from PHC staff, cadres usually feel happy to be involved in every $\mathrm{PHC}$ activity. It can be seen from the proactive of the cadres so far. Another PHC staff stated that community involvement is done in giving opinion and identification of health problem and environmental problems through the survey activity like "Self Assessment Survey" (SMD/survey mawas diri), SMS gateway, cadres meetings, even public aspiration making from the cross sector. The role of health cadres is very active in these activities.

\footnotetext{
"People are happy because they feel inolved in the planning process, it can be seen from the cadre's proactive." (IU-1)
}

Health and a good health status is the most powerful investment or capital base to achieve performance productivity. PHC as a public health facilities at the same time spearhead health services in the community is obliged to provide and give health services according to the needs and particular quality standard. (Brand, 2007). The training and supervisory mechanisms are proven to improve the performance of puskesmas officers in developing countries (Kok et al., 2015) Through the ability in giving service according to the quality standard and community needs, so the 
satisfaction to PHC is getting higher. Patient satisfaction is a widely emphasised indicator of healthcare quality (Sanchez-Piedra et al., 2014).

The research result showed that a high community satisfaction to PHC services increasing the number of visits everyday. Similar to result of Rondonuwu's research at Puskesmas Ranotana Manado that satisfaction is related to the interest of re-utilization of PHC service (Rondonuwu et al., 2014). Also with research of Pardede et al which states the satisfaction of community for the PHC of Kedungmundu services is quite high and does not differ between participants BPJS the PBI and non PBI (Pardede et al., 2016). The similar result is also shown in the study of Tunjungsari et al. (Tunjungsari et al., 2014) All of this can not be separated from the role of PHC personnels who have done their duties well. The impact of the high number of visits is primarily on the high fatigue level of the staffs which later will also affect the PHC performance when the limited human resources (SDM) and other infrastructures problems are not considered. The lack of human resources increases the workload and affects the quality of services provided, as Fai et al's research at the PHC of Oesao Kupang suggests that the partial and simultaneous aspects of the resources affect the quality of neonatal services (Fai et al., 2017). Inadequate system failures and human resource management are key contributors to the provision of not qualified midwifery services in Malawi (Bradley et al., 2015). Problems related to the lack of quantity of health manpower in providing health services and its distribution that has not been evenly distributed in the era of JKN is also a barrier in Tabalong Regency (Saputra, 2013). However, it must be admitted that the lack of officer commitment and supporting from supervisor and management also affect to the low performance of manpower (Maharani, 2009) In addition, community satisfaction may decrease because people have to be more patient with the long queueing time to get the service because of the high visits and the personnels are limited (Prihandari, 2014). Information on satisfaction, based on the perceptions and needs of users, allows policymakers to identify areas for improvement (Sanchez-Piedra et al., 2014)
Health problem is a complex problem because many factors affected by the low health status. To find the soluble solution, community participation and involvement have an accountable portion in the problem solving strategy and the increase of health level, including the health problem concerning with the PHC services (Dharmawan et al., 2015) PHC is an extended hand of government in empowering community for the health development. It is also recognized that so far the $\mathrm{PHC}$ resources are lacking. One of the most effective approaches in overcoming the PHC resources constraints is by involving people (community participation). Health problem is not only the government responsibility, but also the responsibility of all community elements. Community participation is the participation of all community members in an effort of overcoming and solving the community problems, so in this case people are demanded to be active (Kok et al., 2015). The form of participation is not only limited to physical participation, but also in the form of critical awareness of the community that can improve the effectiveness and efficiency of the policy. Community participation is a strong collective action to support policy implementation and resolving health problem (Rokhmah \& Khoiron, 2017).

In the PHC planning mechanism, participation and involvement of the community are needed, both directly or indirectly (Dhewi et al., 2013). From the result of the research, it was found that all PHC informants stated that so far the community have been involved in the planning process of $\mathrm{PHC}$, although it is recognized that the involvement intensity is different from one another. It is acknowledged that the community involvement in the PHC planning process is more emphasized on the situational analysis stage, especially on the problem analysis stage (Dhewi et al., 2013). This result is similar to the study in Papua (Mebri, 2009). Communities can be involved in the identification of health problems that have been occurring that are generally done through SMD activities or surveillance activities conducted as a first step of the situation analysis. In addition, community participation can also be done through efforts 
to identify and solve health problems together, where the ability to identify health problems is influenced by access to health information with a large contribution of $29.48 \%$, leadership (41.86\%) and Self-Assessment Survey (SMD) with $40.07 \%$ contribution, where the effect of all three simultaneously by $53.2 \%$ (Sutisna et al., 2006).

People are involved in health problem identification that have been occuring which generally done by SMD activities or selfobservation survey which is done as the initial stage of situational analysis The form of community involvement in the implementation of the SMD aims to determine the needs of the community and existing and experienced in their area (Dhewi et al., 2013). People and community are expected to give inputs regarding with the problems in their environment, then what are the expectations of community to PHC and how are their opinions concerned with the satisfaction of the service given by $\mathrm{PHC}$ so far. Survey can be conducted using several methods such as: distributing questionnaire, providing suggestion box and writing in a book the identification of needs and expectations. People who are often involved especially Cadre, Village officers, FKD, public figures/religious leader (Toma/Toga) and public. So far, health cadres are already helping the implementation of UKBM, but have not been able to evaluate its implementation, including its reporting to PHC (Anita et al., 2013).

\section{Conclusion}

People generally satisfied with the service of PHC especially in the ease of getting service procedures (not complicated). Nevertheless, there are still some obstacles, especially the limited human resources and facilities that have an impact on the community's discomfort because they have to be patient queuing long enough to get the service. This is a consequence of the rapidly increasing number of PHC visits. The high queue to obtain services is a problem that occurs in all PHC, while the number of health workers who serve remains (limited). The impact of this condition is the high level of fatigue on health personnel and community satisfaction decreased because the waiting time is longer, while the availability of seats for waiting facility availability was limited (become less satisfactory). The Health Office is expected to facilitate with the addition of health personnel, especially at PHC with high daily visits and inpatient services. PHC should also facilitate proper queuing systems and the provision of proper seating facilities for patients while waiting for queues. Communities are also not familiar with the bureaucratic procedures and the prevailing financial mechanisms, and have not been able to distinguish between the needs and desires so that every demands must be fulfilled by $\mathrm{PHC}$ as soon as possible. It takes proactive effort of $\mathrm{PHC}$ to routinely establish communication with the community either through direct meetings with the residents; regular village level/ in RW/RT meetings; visit of Posyandu; home visit; providing suggestion \& information box at PHC and so on. As much as possible the meeting time adjusts to the availability of the community time so that more people can participate.

\section{Acknowledgments}

Thank you to Institute for Research and Community Services Diponegoro University of Semarang who has financed this research through the budget allocation 2016-2017

\section{Reference}

Anita, B., Febriawati, H., \& Yandrizal., 2013. The Role of Public Health Centers (Puskesmas) as the Gatekeeper of National Health Insurance. Jurnal Kesehatan Masyarakat, Kemas, 12(1), pp.76-89.

Bradley, S., Kamwendo, F., Chipeta, E., Chimwaza, W., de Pinho, H., \& McAuliffe, E., 2015. Too Few Staff, Too Many Patients: A Qualitative Study of the Impact on Obstetric Care Providers and on Quality of Care in Malawi. BMC Pregnancy and Childbirth, 15(1), pp.110.

Brand, H., 2007. Good Governance for the Public's Health. European Journal of Public Health, 17(6), pp.541.

Chasanah, U., \& Amanah, L., 2013. Pengukuran Kinerja Berdasarkan Indeks Kepuasan Masyarakat pada Puskesmas Kalirungkut Surabaya. Jurnal Ilmu \& Riset Akuntansi, 2(3), pp.1-25.

Choudhary, G.B., \& Puranik, S., 2014. A Study on Employee Performance Appraisal in Health Care. Asian Journal of Management Science, 2(March), pp.59-64.

Dharmawan, Y., Wigati, P.A., \& Dwijayanti, F., 2015. Kinerja Petugas dalam Pencatatan dan 
Pelaporan PWS KIA di Puskesmas Duren. Jurnal Kesehatan Masyarakat, Kemas, 10(2), pp.210-217.

Dhewi, S.B., Heldy, B., \& Fauzi., 2013. Analisis Perencanaan Tingkat Puskesmas di Kota Medan Tahun 2012. Jurnal Kebijakan, Promosi Kesehatan dan Biostatistik FKMUSU, 2(1), pp.1-7.

Dwiyanto, A., 2003. Reformasi Tata Pemerintahan dan Otonomi Daerah. Yogyakarta. Pusat Studi Kependudukan dan Kebijakan. Universitas Gadjah Mada.

Fai, I.F., Pandie, D.B., \& Ludji, I.D.R.L., 2017. Manajemen Sumberdaya terhadap Mutu Pelayanan Neonatus di Puskesmas PONED Oesao Kupang. Unnes Journal of Public Health, 6(3).

Hasbi, F.H., 2012. Analisis Hubungan Persepsi Pasien tentang Mutu Pelayanan dengan Pemanfaatan Ulang Pelayanan Rawat Jalan Puskesmas Poncol Kota Semarang Tahun 2012. Jurnal Kesehatan Masyarakat, 1(2), pp.11.

Hazilah-Abd-Manaf, N., 2012. Inpatient Satisfaction: an Analysis of Malaysian Public Hospitals. International Journal of Public Sector Management, 25(1), pp.6-16.

Kok, M.C., Dieleman, M., Taegtmeyer, M., Broerse, L.E., Kane, S.S., Ormel, H., Tijm, M.M., \& de Koning, K.A., 2015. Which Intervention Design Factors Influence Performance of Community Health Workers in Low- And Middle-Income Countries? A Systematic Review. Health Policy and Planning, 30(9), pp.1207-1227.

Listyoningrum, L., Dwimawanti, I.H., \& Lestari, H., 2015. Kualitas Pelayanan Kesehatan di Puskesmas Ngaliyan Kota Semarang. Journal of Public Policy and Management Review, 4(2).

Maharani, C., 2009. Sistem Manajemen Mutu ISO 9000 sebagai Alat Peningkatan Kualitas Organisasi Pelayanan Kesehatan. Jurnal Kesehatan Masyarakat, Kemas, 5(1), pp.1-8.

Mebri, I.I., 2009. Evaluasi Proses Perencanaan Tingkat Puskesmas di Lingkungan Dinas Kesehatan Kota Jayapura Provinsi Papua. Universitas Gadjah Mada, Yogyakarta.

Pardede, C.S., Chriswardani, S., \& Wigati, P.A., 2016. Analisis Perbedaan Persepsi Pasien Peserta BPJS terhadap Penilaian Mutu Pelayanan di
Puskesmas Kedungmundu Kota Semarang Tahun 2016. Jurnal Kesehatan Masyarakat, $4(4)$.

Prihandari, H., 2014. Analisis Implementasi Kebijakan Penilaian Kinerja Puskesmas di Kabupaten Jepara Tahun 2012. Thesis. MIKM. Universitas Diponegoro.

Pudjirahardjo, W., \& Sopacua, E., 2006. Kebijakan; Sebuah Kebutuhan dalam Desentralisasi Kesehatan. Buletin Penelitian Sistem Kesehatan. 9, pp.171-177.

Rannan-Eliya, R.P., Wijemanne, N., Liyanage, I.K., Dalpatadu, S., de Alwis, S., Amarasinghe, S., \& Shanthikumar S., 2015. Quality of Inpatient Care in Public and Private Hospitals in Sri Lanka. Health Policy and Planning, 30 (suppl_1), pp.i46-i58.

Rokhmah, D., \& Khoiron., 2017. Building Critical Awareness through HIV and AIDS Management Policy at Sub-Distict and Village Level. Jurnal Kesehatan Masyarakat, Kemas, 13(2), pp.253-260.

Rondonuwu, N.S., Sondakh, R.C., \& Ratag, B.T., 2014. Hubungan antara Kepuasan Pasien terhadap Kualitas Jasa Pelayanan Rawat Jalan dengan Minat untuk Memanfaatkan Kembali Pelayanan Kesehatan di Puskesmas Ranotana Weru Kota Manado Tahun 2014. Skripsi. FKM Unsrat. pp.1-7.

Sanchez-Piedra, C.A., Prado-Galbarro, F.J., GarcíaPérez, S., \& Santamera, A.S., 2014. Factors Associated with Patient Satisfaction with Primary Care in Europe: Results from the EU Primecare Project. Quality in Primary Care, 22, pp.147-155.

Saputra, M., 2013. Program Jaminan Kesehatan Nasional dari Aspek Sumber Daya Manusia Pelaksana Pelayanan Kesehatan. Jurnal Kesehatan Masyarakat, Kemas, 8(2), pp.113120.

Sutisna, E.S., Karsidi, R., Murti, B., Kartono, D.T., Waryana., \& Rifai, H., 2006. Model Pemberdayaan Masyarakat Bidang Kesehatan, Studi Program Desa Siaga. Jurnal Kesehatan Masyarakat Nasional, 7(36), pp.186-192.

Tunjungsari, I.P., Sulandari, S., \& Fathurrochman., 2014. Analisis Indeks Kepuasan Pasien di Puskesmas Kedungmundu Kota Semarang. Journal of Public Policy and Management Review, 3(2), pp.1-10. 